
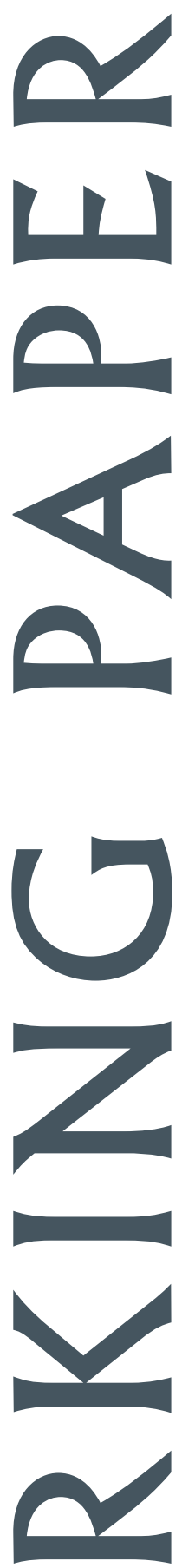

EAST-WEST CENTER 
The East-West Center is an education and research organization established by the U.S. Congress in 1960 to strengthen relations and understanding among the peoples and nations of Asia, the Pacific, and the United States. The Center contributes to a peaceful, prosperous, and just Asia Pacific community by serving as a vigorous hub for cooperative research, education, and dialogue on critical issues of common concern to the Asia Pacific region and the United States. Funding for the Center comes from the U.S. government, with additional support provided by private agencies, individuals, foundations, corporations, and the governments of the region.

East-West Center Working Papers are circulated for comment and to inform interested colleagues about work in progress at the Center.

For more information about the Center or to order publications, contact:

Publication Sales Office

East-West Center

1601 East-West Road

Honolulu, Hawai'i 96848-1601

Telephone: 808.944.7145

Facsimile: 808.944.7376

Email: ewcbooks@EastWestCenter.org

Website: www.EastWestCenter.org 


\title{
Economics Series
}

No. 105, December 2009

\section{Climate Change Meets Trade in Promoting Green Growth: Potential Conflicts and Synergies}

\author{
ZhongXiang Zhang
}

ZhongXiang Zhang is a Senior Fellow at the East-West Center. Currently, he is a co-editor of International Journal of Ecological Economics and Statistics, and serves on the editorial boards of seven leading international journals and one Chinese journal. Eleven of his publications are cited by IPCC Climate Change 2001: Mitigation and IPCC Climate Change 2007: Mitigation of Climate Change, making him one of the most cited authors in that two extremely comprehensive and authoritative publications on mitigating climate change and the associated costs.

Invited presentation at the East-West Center/Korea Development Institute International Conference on Climate Change and Green Growth: Korea's National Growth Strategy, Honolulu, Hawaii, July 23-24, 2009.

East-West Center Working Papers: Economics Series is an unreviewed and unedited prepublication series reporting on research in progress. The views expressed are those of the author and not necessarily those of the Center. Please direct orders and requests to the East-West Center's Publication Sales Office. The price for Working Papers is $\$ 3.00$ each plus shipping and handling. 
This version: July 15, 2009

\title{
Climate Change Meets Trade in Promoting Green Growth: Potential Conflicts and Synergies $^{1}$
}

\author{
ZhongXiang Zhang Ph.D in Economics \\ 张中祥 美国东西方中心研究部资深研究员、经济学博士 \\ Senior Fellow \\ Research Program \\ East-West Center \\ 1601 East-West Road \\ Honolulu, HI 96848-1601 \\ United States \\ Tel: $+1-808-9447265$ \\ Fax: +1-808-944 7298 \\ Email: ZhangZ@EastWestCenter.org
}

\begin{abstract}
To date, border adjustment measures in the form of emissions allowance requirements (EAR) under the U.S. proposed cap-and-trade regime are the most concrete unilateral trade measure put forward to level the carbon playing field. If improperly implemented, such measures could disturb the world trade order and trigger a trade war. Because of these potentially far-reaching impacts, this paper focuses on this type of unilateral border adjustment, which requires importers to acquire and surrender emissions allowances corresponding to the embedded carbon contents in their goods from countries that have not taken climate actions comparable to that of home country. This discussion is mainly on the legality of unilateral EAR under the WTO rules. Given that the inclusion of border carbon adjustment measures is widely considered essential to secure passage of any U.S. legislation capping its greenhouse gas emissions, the paper argues that, on the U.S. side, in designing such trade measures, WTO rules need to be carefully scrutinised, and efforts need to be made early on to ensure that the proposed measures comply with them. After

\footnotetext{
${ }^{1}$ Invited presentation at the East-West Center/Korea Development Institute Conference on Climate Change and Green Growth: Korea’s National Growth Strategy, Honolulu, Hawaii, July 23-24, 2009.
} 
all, a conflict between the trade and climate regimes, if it breaks out, helps neither trade nor the global climate. The U.S. needs to explore, with its trading partners, cooperative sectoral approaches to advancing low-carbon technologies and/or concerted mitigation efforts in a given sector at an international level. Moreover, to increase the prospects for a successful WTO defence of the Waxman-Markey type of border adjustment provision, there should be: 1) a period of good faith efforts to reach agreements among the countries concerned before imposing such trade measures; 2) consideration of alternatives to trade provisions that could be reasonably expected to fulfill the same function but are not inconsistent or less inconsistent with the relevant WTO provisions; and 3) trade provisions that can refer to the designated special international reserve allowance pool, but should allow importers to submit equivalent emission reduction units that are recognized by international treaties to cover the carbon contents of imported products. The paper concludes by arguing that the major developing countries being targeted by such border carbon adjustment measures should make the best use of the forums provided under the United Nations Framework Convention on Climate Change and its Kyoto Protocol to effectively deal with the proposed border adjustment measures to their advantage.

JEL classification: F18; Q48; Q54; Q56; Q58

Keywords: Post-2012 climate negotiations; Border carbon adjustments; Carbon tariffs; Emissions allowance requirements; Cap-and-trade regime; Lieberman-Warner bill; WaxmanMarkey bill; World Trade Organization; Kyoto Protocol; Developing countries; United States 


\section{Introduction}

Climate and trade policies both affect the use of natural resources. Their linkages are recognized in the objectives of the corresponding agreements to safeguard the two regimes. The ultimate objective of the United Nations Framework Convention on Climate Change (UNFCCC) is to stabilize greenhouse gas concentrations in the atmosphere. An underlying principle to guide this effort is that "measures taken to combat climate change, including unilateral ones, should not constitute a means of arbitrary or unjustifiable discrimination or a disguised restriction on international trade.” At the same time, the World Trade Organization (WTO) Agreement recognizes that trade should be conducted "while allowing for the optimal use of the world's resources in accordance with the objective of sustainable development, seeking both to provide and preserve the environment and to enhance the means for doing so.”

Clearly, the main aim of both the UNFCCC and the WTO is to ensure efficiency in the use of resources, from the perspective of either maximizing the gains from the comparative advantage of nations through trade or ensuring that economic development is environmentally sustainable. Therefore, the objectives of the UNFCCC (and its Kyoto Protocol) and the WTO do not explicitly conflict with each other.

However, the possibility of conflicts may arise in implementing the Kyoto Protocol (KP) and any international regime to succeed it as countries aim for green growth. With greenhouse gas emissions embodied in virtually all products produced and traded in every conceivable economic sector, effectively addressing climate change will require a fundamental transformation of our economy and the ways energy is produced and used. This will certainly have a bearing on world trade because it will affect the costs of production of traded products and therefore their competitive positions in the world market. This climate-trade nexus has become the focus of an academic debate (e.g., Bhagwati and Mavroidis, 2007; Charnovitz, 2003; Ismer and Neuhoff, 2007; Swedish National Board of Trade, 2004; The World Bank, 2007; Zhang, 1998, 2004 and 2007a; Zhang and Assunção, 2004), and gains increasing attention as governments are taking great efforts to implement the KP and forge a post-2012 climate change regime to succeed it. 
To comply with the KP, Annex 1 countries are preparing, adopting and implementing comprehensive measures to meet their emissions targets set under the Protocol. The KP gives these countries considerable flexibility in the choice of domestic policies to meet their emissions commitments. Possible climate measures include carbon/energy taxes, subsidies, energy efficiency standards, eco-labels, government procurement policies, and flexibility mechanisms build into the Kyoto Protocol. The implementation of these measures has the potential to affect trade and thus raises concerns about compatibility with WTO rules.

In order to meet their Kyoto emissions targets or/and stimulate their economies with minimum adverse effects, it is very likely that Annex 1 governments with differentiated legal and political systems might pursue emission reduction policies in such a way as to favor domestic producers over foreign ones. Such differential treatment could occur in governing eligibility for, and the amount of, a subsidy, in establishing energy efficiency standards, in determining the category of eco-labeled products and the procedures for establishing eco-labels, and in specifying criteria for tenders and condition for participating in government procurement bids as "Buy American" type of provisions biases for U.S. home-made goods under its stimulus package. In the case where a country unilaterally imposes a carbon tax or a cap-and-trade regime, it may adjust taxes or carbon contents of traded products at the border to mitigate competitiveness effects of cheaper imports not subject to a similar level of the carbon tax or emission limits in the country of origin. Measures of this sort raise complex questions with respect to their WTO consistency and the conditions under which border taxes or border carbon contents of traded products can be adjusted to accommodate a loss of international competitiveness. ${ }^{2}$

This climate-trade nexus becomes intensive as countries are developing post-2012 climate commitments on the basis of the Bali roadmap, which was agreed to at the UNFCCC Conference of Parties meeting in December 2007, with a clear deadline for conclusion by 2009 at Copenhagen. No one would disagree that the U.S. commitment to cut emissions is essential to such a global pact and President Obama's desire to lead after what is viewed as eight years of lost time under President Bush. However, much of Obama’s ability to move forward in

\footnotetext{
${ }^{2}$ See Zhang (1998 and 2007a), Zhang and Assunção (2004), and Charnovitz (2003) for broad discussion on potential conflicts and synergies between climate and trade regimes.
} 
international climate negotiations rests with the U.S. Congress, because the Obama administration will likely be in the position to agree to a specific emission target that the whole world has long waited only when the Congress has enacted or is on the verge of enacting legislation capping U.S. greenhouse gas emissions.

The Intergovernmental Panel on Climate Change calls for developed countries to cut their greenhouse gas emissions by $25-40 \%$ by 2020 and by $80 \%$ by 2050 relative to their 1990 levels, in order to avoid dangerous climate change impacts. In the meantime, under the UNFCCC principle of "common but differentiated responsibilities," developing countries are allowed to move at different speeds as do their developed counterparts. This principle is clearly reflected in the Bali roadmap, which requires developing countries to take "nationally appropriate mitigation actions... in the context of sustainable development, supported and enabled by technology, financing and capacity-building, in a measurable, reportable and verifiable manner.” Understandably, the U.S. and other industrialized countries would like to see developing countries, in particular large developing economies, go beyond that because of concerns about their own competitiveness and growing greenhouse gas emissions in developing countries. They are considering unilateral trade measures to "induce" developing countries to do so. This has been the case in the course of debating and voting the U.S. congressional climate bills capping U.S. greenhouse gas emissions. U.S. legislators have pushed for major emerging economies, such as China and India, to take comparable climate actions as U.S. does. Otherwise, their products sold on the U.S. market will have to purchase and surrender emissions allowances to cover their carbon contents. This kind of border carbon adjustment measures has raised great concerns about whether they are WTO-consistent and has received heavy criticisms from developing countries.

To date, border adjustment measures in the form of emissions allowance requirements (EAR) under the U.S. proposed cap-and-trade regime are the most concrete unilateral trade measure put forward on the table to level the carbon playing field. If improperly implemented, such measures could disturb the world trade order and trigger a trade war. Because of these potentially farreaching impacts, this paper will focus on this type of unilateral border adjustment. It requires importers to acquire and surrender emissions allowances corresponding to the embedded carbon 
contents in their goods from countries that have not taken climate actions comparable to that of the home country. My discussion is mainly on the legality of unilateral EAR under the WTO rules. ${ }^{3}$ Section 2 briefly describes the border carbon adjustment measures proposed in the U.S. legislations. Section 3 deals with the WTO scrutiny of EAR proposed in the U.S. congressional climate bills. Section 4 briefly discusses whether an EAR threat would be effective as an inducement for major emerging economies to take climate actions that they would otherwise not as well as methodological challenges in implementing EAR. The paper ends with some concluding remarks on the needs on the U.S. side to minimize the potential conflicts with WTO provisions in designing such border carbon adjustment measures, and with suggestion for major developing countries being targeted by such border measures to effectively deal with the proposed border adjustment measures to their advantage.

\section{Proposed border adjustment measures in the U.S. legislations}

The notion of border carbon adjustments (BCA) is not an American invention. The idea of using BCA to address the competitiveness concerns as a result of differing climate policy was first floated in the EU, in response to the U.S. withdrawal from the Kyoto Protocol. Dominique de Villepin, the then French prime minister, proposed in November 2006 for carbon tariffs on goods from countries that had not ratified the Kyoto Protocol. He clearly had the U.S. in mind when contemplating such proposals aimed to bring the U.S. to the table for climate negotiations. However, Peter Mandelson, the then EU trade commissioner, dismissed the French proposal as not only a probable breach of trade rules but also "not good politics” (Bounds, 2006). As a balanced reflection of the divergent views on this issue, the European Commission has suggested that it could implement a "carbon equalization system ... with a view to putting EU and non-EU producers on a comparable footing." "Such a system could apply to importers of goods requirements similar to those applicable to installations within the European Union, by requiring the surrender of allowances.” (European Commission, 2008). While the EU has considered the

\footnotetext{
${ }^{3}$ See Reinaud (2008) for an excellent review of practical issues involved in implementing unilateral EAR.
} 
possibility of imposing a border allowance adjustment should serious leakage issues arise in the future, it has put this option on hold at least until 2012. The European Commission has proposed using temporary free allocations to address competitiveness concerns in the interim. Its aim is to facilitate a post-2012 climate negotiation while keeping that option in the background as a last resort.

Interestingly, the U.S. legislators have not only embraced such BCA measures that they were opposed to, but have also focused on their design issues in more details. In the U.S. Senate, the Boxer Substitute of the Lieberman-Warner Climate Security Act (S. 3036) mandates that starting from 2014 importers of products covered by the cap-and-trade scheme would have to purchase emissions allowances from an International Reserve Allowance Programme if no comparable climate action were taken in the exporting country. Least developed countries and countries that emit less than $0.5 \%$ of global greenhouse gas emissions (i.e., those being considered not significant emitters) would be excluded from the scheme. Given that most carbon-intensive industries in the U.S. run a substantial trade deficit (Houser et al., 2008), this proposed EAR clearly aims to level the carbon playing field for domestic producers and importers. In the U.S. House of Representatives, the American Clean Energy and Security Act of 2009 (H.R. 2998), ${ }^{4}$ sponsored by Reps. Henry Waxman (D-CA) and Edward Markey (D-MA), was narrowly passed on June 26, 2009. The so-called Waxman-Markey bill sets up an "International Reserve Allowance Program” whereby U.S. importers of primary emission-intensive products from countries having not taken "greenhouse gas compliance obligations commensurate with those that would apply in the United States” would be required to acquire and surrender carbon emissions allowances. The EU by any definition would pass this comparability test, because it has taken under the Kyoto Protocol and is going to take in its follow-up regime much more ambitious climate targets than U.S. Because all other remaining Annex 1 countries but the U.S. have accepted mandatory emissions targets under the Kyoto Protocol, these countries would likely pass the comparability test as well, which exempts them from EAR under the U.S. proposed cap-and-trade regime. While France targeted the American goods, the U.S. EAR clearly targets major emerging economies, such as China and India.

\footnotetext{
${ }^{4}$ H.R. 2998, available at: http://frwebgate.access.gpo.gov/cgibin/getdoc.cgi?dbname=111_cong_bills\&docid=f:h2998ih.txt.pdf.
} 


\section{WTO scrutiny of U.S. Congressional climate bills}

The import emissions allowance requirement was a key part of the Lieberman-Warner Climate Security Act of 2008, and will re-appear again as the U.S. Senate starts writing, debating and voting its own version of a climate change bill later 2009 after the U.S. House of Representatives narrowly passed the Waxman-Markey bill. Moreover, concerns raised in the Lieberman-Warner bill seem to have provided references to writing relevant provisions in the Waxman-Markey bill to deal with the competitiveness concerns. For these reasons, I start with the Lieberman-Warner bill.

A proposal first introduced by the International Brotherhood of Electrical Workers (IBEW) and American Electric Power (AEP) in early 2007 would require importers to acquire emission allowances to cover the carbon content of certain products from countries that do not take climate actions comparable to that of the U.S. (Morris and Hill, 2007). The original version of the Lieberman-Warner bill incorporated this mechanism, threatening to punish energy-intensive imports from developing countries by requiring importers to obtain emission allowance, but only if they had not taken comparable actions by 2020, eight years after the effective start date of a U.S. cap-and-trade regime begins. It was argued that the inclusion of trade provisions would give the U.S. additional diplomatic leverage to negotiate multilaterally and bilaterally with other countries on comparable climate actions. Should such negotiations not succeed, trade provisions would provide a means of leveling the carbon playing field between American energy-intensive manufacturers and their competitors in countries not taking comparable climate actions. Not only would the bill have imposed an import allowance purchase requirement too quickly, it would have also dramatically expanded the scope of punishment: almost any manufactured product would potentially have qualified. If strictly implemented, such a provision would pose an insurmountable hurdle for developing countries (The Economist, 2008).

It should be emphasized that the aim of including trade provisions is to facilitate negotiations while keeping open the possibility of invoking trade measures as a last resort. The latest version of the Lieberman-Warner bill has brought the deadline forward to 2014 to gain business and 
union backing. ${ }^{5}$ The inclusion of trade provisions might be considered the "price" of passage for any U.S. legislation capping its greenhouse gas emissions. Put another way, it is likely that no climate legislation can move through U.S. Congress without dealing with the issue of trade provisions. An important issue on the table is the length of the grace period to be granted to developing countries. While many factors need to be taken into consideration here (Haverkamp, 2008), further bringing forward the imposition of allowance requirements to imports is rather unrealistic, given the already very short grace period ending 2019 in the original version of the bill. It should be noticed that the Montreal Protocol on Substances that Deplete the Ozone Layer grants developing countries a grace period of 10 years (Zhang, 2000). Given that the scope of economic activities affected by a climate regime is several orders of magnitude larger than those covered by the Montreal Protocol, if legislation incorporates border adjustment measures (put the issue of their WTO consistency aside), in my view, they should not be invoked for at least 10 years after mandatory U.S. emission targets take effect.

Moreover, unrealistically shortening the grace period granted before resorting to the trade provisions would increase the uncertainty of whether the measure would withstand a challenge by U.S. trading partners before the WTO. As the ruling in the Shrimp-Turtle dispute indicates (see Box 2), for a trade measure to be considered WTO-consistent, a period of good-faith efforts to reach agreements among the countries concerned is needed before imposing such trade measures. Put another way, trade provisions should be preceded by major efforts to negotiate with partners within a reasonable timeframe. Furthermore, developing countries need reasonable time to develop and operate national climate policies and measures. Take the establishment of an emissions trading scheme as a case in point. Even for the U.S. $\mathrm{SO}_{2}$ Allowance Trading Program, the entire process from the U.S. Environmental Protection Agency beginning to compile the data for its allocation database in 1989 to publishing its final allowance allocations in March 2003 took almost four years. For the first phase of the EU Emissions Trading Scheme, the entire process took almost two years from the EU publishing the Directive establishing a scheme for greenhouse gas emission allowance trading on 23 July 2003 to it approving the last national

\footnotetext{
${ }^{5}$ This is in line with the IBEW/AEP proposal, which requires U.S. importers to submit allowances to cover the emissions produced during the manufacturing of those goods two years after U.S. starts its cap-and-trade program (McBroom, 2008).
} 
allocation plan for Greece on 20 June 2005. For developing countries with very weak environmental institutions and that do not have dependable data on emissions, fuel uses and outputs for installations, this allocation process is expected to take much longer than what experienced in the U.S. and the EU (Zhang, 2007b).

\section{Box 1 Core WTO principles}

GATT Article 1 ('most favored nation' treatment): WTO members not allowed to discriminate against like imported products from other WTO members

GATT Article III ('national treatment'): Domestic and like imported products treated identically, including any internal taxes and regulations

GATT Article XI ('elimination of quantitative restrictions'): Forbids any restrictions (on other WTO members) in the form of bans, quotas or licenses

\section{GATT Article XX}

"Subject to the requirement that such measures are not applied in a manner which would constitute a means of arbitrary or unjustifiable discrimination between countries where the same conditions prevail, or a disguised restriction on international trade, nothing in this Agreement shall be constructed to prevent the adoption or enforcement by any contracting party of measures...

(b) necessary to protect human, animal or plant life or health; ...

(g) relating to the conservation of exhaustible natural resources if such measures are made effective in conjunction with restrictions on domestic production or consumption; ...”

The threshold for (b) is higher than for (g), because, in order to fall under (b), the measure must be "necessary", rather than merely "relating to" under (g).

\section{Box 2 Implications of the findings of WTO the shrimp-turtle dispute}

To address the decline of sea turtles around the world, in 1989 the U.S. Congress enacted Section 609 of Public Law 101-162 to authorize embargoes on shrimp harvested with commercial fishing technology harmful to sea turtles. The U.S. was challenged in the WTO by India, Malaysia, Pakistan and Thailand in October 1996, after embargoes were leveled against them. The four governments challenged this measure, asserting that the U.S. could not apply its laws to foreign process and production methods. A WTO Dispute Settlement Panel was established in April 1997 to hear the case. The Panel found that the U.S. failed to approach the complainant nations in serious multilateral negotiations before enforcing the U.S. law against those nations. The Panel held that the U.S. shrimp embargo was a class of measures of processes-and-productionmethods type and had a serious threat to the multilateral trading system because it conditioned 
market access on the conservation policies of foreign countries. Thus, it cannot be justified under GATT Article XX. However, the WTO Appellate Body overruled the Panel's reasoning. The Appellate Body held that a WTO member requires from exporting countries compliance, or adoption of, certain policies prescribed by the importing country does not render the measure inconsistent with the WTO obligation. Although the Appellate Body still found that the U.S. shrimp embargo was not justified under GATT Article XX, the decision was not on ground that the U.S. sea turtle law itself was not inconsistent with GATT. Rather, the ruling was on ground that the application of the law constituted "arbitrary and unjustifiable discrimination" between WTO members (WTO, 1998). The WTO Appellate Body pointed to a 1996 regional agreement reached at the U.S. initiation, namely the Inter-American Convention on Protection and Conservation of Sea Turtles, as evidence of the feasibility of such an approach (WTO, 1998; Berger, 1999). Here, the Appellate Body again advanced the standing of multilateral environmental treaties (Zhang, 2004; Zhang and Assunção, 2004). Thus, it follows that this trade dispute under the WTO may have been interpreted as a clear preference for actions taken pursuant to multilateral agreements and/or negotiated through international cooperative arrangements, such as the Kyoto Protocol and its successor. However, this interpretation should be with great caution, because there is no doctrine of stare decisis (namely, "to stand by things decided”) in the WTO; the GATT/WTO panels are not bound by previous panel decisions (Zhang and Assunção, 2004).

Moreover, the WTO Shrimp-Turtle dispute settlement has a bearing on the ongoing discussion on the "comparability" of climate actions in a post-2012 climate change regime. The Appellate Body found that when the U.S. shifted its standard from requiring measures essentially the same as the U.S. measures to "the adoption of a program comparable in effectiveness", this new standard would comply with the WTO disciplines (WTO, 2001, paragraph 144). Some may view that this case opens the door for U.S. climate legislation that bases trade measures on an evaluation of the comparability of climate actions taken by other trading countries. Comparable action can be interpreted as meaning action comparable in effect as the "comparable in effectiveness" in the Shrimp-Turtle dispute. It can also be interpreted as meaning "the comparability of efforts". The Bali Action Plan adopts the latter interpretation, using the terms comparable as a means of ensuring that developed countries undertake commitments comparable to each other (Zhang, 2009a).

In the case of a WTO dispute, the question will arise whether there are any alternatives to trade provisions that could be reasonably expected to fulfill the same function but are not inconsistent or less inconsistent with the relevant WTO provisions. Take the GATT Thai cigarette dispute as a case in point. Under Section 27 of the Tobacco Act of 1966, Thailand restricted imports of cigarettes and imposed a higher tax rate on imported cigarettes when they were allowed on the three occasions since 1966, namely in 1968-70, 1976 and 1980. After consultations with Thailand failed to lead to a solution, the U.S. requested in 1990 the Dispute Settlement Panel to rule on the Thai action on the grounds that it was inconsistent with Article XI:1 of the General 
Agreement; was not justified by the exception under Article XI:2(c), because cigarettes were not an agricultural or fisheries product in the meaning of Article XI:1; and was not justified under Article XX(b) because the restrictions were not necessary to protect human health, i.e. controlling the consumption of cigarettes did not require an import ban. The Dispute Settlement Panel ruled against Thailand. The Panel found that Thailand had acted inconsistently with Article XI:1 for having not granted import licenses over a long period of time. Recognizing that XI:2(c) allows exceptions for fisheries and agricultural products if the restrictions are necessary to enable governments to protect farmers and fishermen who, because of the perishability of their produce, often could not withhold excess supplies of the fresh product from the market, the Panel found that cigarettes were not "like" the fresh product as leaf tobacco and thus were not among the products eligible for import restrictions under Article XI:2(c). Moreover, the Panel acknowledged that Article XX(b) allowed contracting parties to give priority to human health over trade liberalization. The Panel held the view that the import restrictions imposed by Thailand could be considered to be "necessary" in terms of Article XX(b) only if there were no alternative measure consistent with the General Agreement, or less inconsistent with it, which Thailand could reasonably be expected to employ to achieve its health policy objectives. However, the Panel found the Thai import restriction measure not necessary because Thailand could reasonably be expected to take strict, non-discriminatory labelling and ingredient disclosure regulations and to ban all the direct and indirect advertising, promotion and sponsorship of cigarettes to ensure the quality and reduce the quantity of cigarettes sold in Thailand. These alternative measures are considered WTO-consistent to achieve the same health policy objectives as Thailand now pursues through an import ban on all cigarettes whatever their ingredients (GATT, 1990). Simply put, in the GATT Thai cigarette dispute, the Dispute Settlement Panel concluded that Thailand had legitimate concerns with health but it had measures available to it other than a trade ban that would be consistent with the General Agreement on Tariffs and Trade (e.g. bans on advertising) (GATT, 1990).

Indeed, there are alternatives to resorting to trade provisions to protect the U.S. trade-sensitive, energy-intensive industries during a period when the U.S. is taking good-faith efforts to negotiate with trading partners on comparable actions. One way to address competitiveness concerns is to initially allocate free emission allowances to those sectors vulnerable to global competition, 
either totally or partially. ${ }^{6}$ Bovenberg and Goulder (2002) found that giving out about $13 \%$ of the allowances to fossil fuel suppliers freely instead of auctioning in an emissions trading scheme in the U.S. would be sufficient to prevent their profits with the emissions constraints from falling in comparison with those without the emissions constraints.

There is no disagreement that the allocation of permits to emissions sources is a politically contentious issue. Grandfathering, or at least partially grandfathering, helps these well-organized, politically highly-mobilized industries or sectors to save considerable expenditures and thus increases the political acceptability of an emissions trading scheme, although it leads to a higher economic cost than a policy where the allowances are fully auctioned. ${ }^{7}$ This explains why the sponsors of the American Clean Energy and Security Act of 2009 had to make a compromise amending the Act to auction only 15\% of the emission permits instead of the initial proposal for auctioning all the emission permits in a proposed cap-and-trade regime. This change allowed the U.S. House of Representatives Energy and Commerce Committee to pass the Act in May 2009. However, it should be pointed out that although grandfathering is thought of as giving implicit subsidies to these sectors, grandfathering is less trade-distorted than the exemptions from carbon taxes (Zhang, 1998 and 1999), which means that partially grandfathering is even less tradedistorted than the exemptions from carbon taxes. To understand their difference, it is important to bear in mind that grandfathering itself also implies an opportunity cost for firms receiving permits: what matters here is not how firms get your permits, but what firms can sell them for that is what determines opportunity cost. Thus, even if permits are awarded gratis, firms will

${ }^{6}$ To be consistent with the WTO provisions, foreign producers could arguably demand the same proportion of free allowances as U.S. domestic producers in case they are subject to border carbon adjustments.

${ }^{7}$ In a second-best setting with pre-existing distortionary taxes, if allowances are auctioned, the revenues generated can then be used to reduce pre-existing distortionary taxes, thus generating overall efficiency gains. Parry et al. (1999), for example, show that the costs of reducing U.S. carbon emissions by $10 \%$ in a second-best setting with pre-existing labor taxes are five times more costly under a grandfathered carbon permits case than under an auctioned case. This is because the policy where the permits are auctioned raises revenues for the government that can be used to reduce pre-existing distortionary taxes. By contrast, in the former case, no revenuerecycling effect occurs, since no revenues are raised for the government. However, the policy produces the same tax-interaction effect as under the latter case, which tends to reduce employment and investment and thus exacerbates the distortionary effects of pre-existing taxes (Zhang, 1999). 
value them at their market price. Accordingly, the prices of energy will adjust to reflect the increased scarcity of fossil fuels. This means that regardless of whether emissions permits are given out freely or are auctioned by the government, the effects on energy prices are expected to be the same, although the initial ownership of emissions permits differs among different allocation methods. As a result, relative prices of products will not be distorted relative to their pre-existing levels and switching of demand towards products of those firms whose permits are awarded gratis (the so-called substitution effect) will not be induced by grandfathering. This makes grandfathering different from the exemptions from carbon taxes. In the latter case, there exist substitution effects (Zhang, 1998 and 1999). For example, the Commission of the European Communities (CEC) proposal for a mixed carbon and energy tax ${ }^{8}$ provides for exemptions for the six energy-intensive industries (i.e., iron and steel, non-ferrous metals, chemicals, cement, glass, and pulp and paper) from coverage of the CEC tax on grounds of competitiveness. This not only reduces the effectiveness of the CEC tax in achieving its objective of reducing $\mathrm{CO}_{2}$ emissions, but also makes the industries, which are exempt from paying the CEC tax, improve their competitive position in relation to those industries which are not. Therefore, there will be some switching of demand towards the products of these energy-intensive industries, which is precisely the reaction that such a tax should avoid (Zhang, 1997).

The import allowance requirement approach would distinguish between two otherwise physically identical products on the basis of climate actions in place in the country of origin. This discrimination of like products among trading nations would constitute a prima facie violation of WTO rules. To pass WTO scrutiny of trade provisions, the U.S. is likely to make reference to the health and environmental exceptions provided under GATT Article XX (see Box 1). This Article itself is the exception that authorizes governments to employ otherwise GATT-illegal measures when such measures are necessary to deal with certain enumerated public policy problems. The

\footnotetext{
${ }^{8}$ As part of its comprehensive strategy to control $\mathrm{CO}_{2}$ emissions and increase energy efficiency, a carbon/energy tax has been proposed by the CEC. The CEC proposal is that member states introduce a carbon/energy tax of US\$ 3 per barrel oil equivalent in 1993, rising in real terms by US\$ 1 a year to US\$ 10 per barrel in 2000. After the year 2000 the tax rate will remain at US\$ 10 per barrel at 1993 prices. The tax rates are allocated across fuels, with 50\% based on carbon content and 50\% on energy content (Zhang, 1997).
} 
GATT panel in Tuna/Dolphin II concluded that Article XX does not preclude governments from pursuing environmental concerns outside their national territory, but such extra-jurisdictional application of domestic laws would be permitted only if aimed primarily (emphasis added) at having a conservation or protection effect (GATT, 1994; Zhang, 1998). The capacity of the planet's atmosphere to absorb greenhouse gas emissions without adverse impacts is an 'exhaustible natural resource.' Thus, if countries take measures on their own including extrajurisdictional application primarily to prevent the depletion of this 'exhaustible natural resource,' such measures will have a good justification under GATT Article XX. Along this reasoning, if the main objective of trade provisions is to protect the environment by requiring other countries to take actions comparable to that of the U.S., then mandating importers to purchase allowances from the designated special international reserve allowance pool to cover the carbon emissions associated with the manufacture of that product is debatable. To increase the prospects for a successful WTO defense, I think that trade provisions can refer to the designated special international reserve allowance pool, but may not do without adding "or equivalent.” This will allow importers to submit equivalent emission reduction units that are not necessarily allowances but are recognized by international treaties to cover the carbon contents of imported products.

Clearly, these concerns raised in the Lieberman-Warner bill have shaped relevant provisions in the Waxman-Markey bill to deal with the competitiveness and leakage concerns. Accordingly, the Waxman-Markey bill has avoided all the aforementioned controversies raised in the Lieberman-Warner bill. Unlike the EAR in the Lieberman-Warner bill which focuses exclusively on imports into the U.S., but does nothing to address the competitiveness of U.S. exports in foreign markets, the Waxman-Markey bill included both rebates for few energy-intensive, tradesensitive sectors ${ }^{9}$ and free emission allowances to help not to put U.S. manufacturers at a disadvantage relative to overseas competitors. Unlike the Lieberman-Warner bill in the U.S. Senate, the Waxman-Markey bill also gives China, India and other major developing nations time to enact their climate-friendly measures. Under the Waxman-Markey bill, the International Reserve Allowance Program may not begin before January 1, 2025. The U.S. President may only implement an International Reserve Allowance Program for sectors producing primary products.

\footnotetext{
${ }^{9}$ See Genasci (2008) for discussion on complicating issues related to how to rebate exports under a cap-and-trade regime.
} 
While the bill called for a "carbon tariff" on imports, it very much framed that measures as a last resort that a U.S. president could impose at his or her discretion regarding border adjustments or tariffs. However, in the middle of the night before the vote on June 26, 2009, a provision was inserted in this House bill that requires the President, starting in 2020, to impose a border adjustment - or tariffs - on certain goods from countries that do not act to limit their greenhouse gas emissions. The President can waive the tariffs only if he receives explicit permission from U.S. Congress (Broder, 2009). The last-minute changes in the bill changed a Presidential longterm back-up option to a requirement that the President put such tariffs in place under the specified conditions. Such changes significantly changed the spirit of the bill, moving it considerably closer to risky protectionism. While praising the passage of the House bill as an “extraordinary first step," President Obama opposed a trade provision in that bill. ${ }^{10}$ The carbon tariff proposals have also drawn fierce criticism from China and India. Without specific reference to the U.S. or the Waxman-Markey bill, China’s Ministry of Commerce said in a statement posted on its website that proposals to impose "carbon tariffs" on imported products will violate the rules of the World Trade Organization. That would enable developed countries to "resort to trade in the name of protecting the environment." The carbon tariff proposal runs against the principle of "common but differentiated responsibilities," the spirit of the Kyoto Protocol. This will neither help strengthen confidence that the international community can cooperate to handle the (economic) crisis, nor help any country's endeavors during the climate change negotiations. Thus China is strongly opposed to it (MOC of China, 2009).

\section{Ineffective inducement and methodological challenges}

Proponents of an EAR argue that such a threat would be effective as an inducement for major emerging economies to take on such level of climate actions that U.S. legislations aim. However, this is questionable. The EAR under the U.S. proposed cap-and-trade regime would not apply to all imports. Rather, it would specifically target those primary emission-intensive products, such

\footnotetext{
${ }^{10}$ President Obama was quoted as saying that "At a time when the economy worldwide is still deep in recession and we've seen a significant drop in global trade, I think we have to be very careful about sending any protectionist signals out there. I think there may be other ways of doing it than with a tariff approach.” (Broder, 2009).
} 
as steel, aluminium, and cement. Indeed, China has become a key producer of these primary products, accounting for $36 \%$ of global steel production, 32\% of global aluminium production and over $50 \%$ of global cement production in 2007. The logic for the threat of EAR lies that the fear of losing market access for these products would be enough to jawbone China to take climate actions that it would otherwise not. However, the problem with this logic is that China's burgeoning supply of these carbon-intensive products is not mainly destined for export. Rather, they are made in China for China, going primarily to meet Chinese own demand. As the world's largest steel export, China only exported $2 \%$ of its steel production to the EU and less than $1 \%$ to the U.S. in 2007. As the world's largest cement producer and exporter, China consumed $97 \%$ of its cement domestically, and exported less than 1\% of its production to the U.S. in 2007 (Houser, 2008; Houser et al., 2008). Even if EAR is implemented jointly with the EU, it has little leverage effect on China because China is unlikely to raise the cost of producing $97 \%$ of its output for domestic market in order to protect a market of less than $3 \%$ of its production abroad. Moreover, this effect on the targeted country will be further alleviated by re-routing trade flows to deliver the covered products from countries that are not subject to the EAR scheme. With Japan passing the comparability test and thus being exempted from an EAR under the proposed U.S. cap-andtrade regime, imposing an EAR on Chinese steel, but not on Japanese steel, could make Japanese steel more competitive in the U.S. market than Chinese steel. That could lead Japanese steel makers to sell more steel to the U.S. and Japanese steel consumers to import more from China (Houser et al., 2008). In the end, this neither affects on China nor protects U.S. steel producers.

Besides the issue of WTO consistency and the ineffectiveness of EAR in leveraging developing countries to change behaviors, there will be methodological challenges in implementing an EAR under a cap-and-trade regime, although such practical implementation issues are secondary concerns. Identifying the appropriate carbon contents embodied in traded products will present formidable technical difficulties, given the wide range of technologies in use around the world and very different energy resource endowments and consumption patterns among countries. In the absence of any information regarding the carbon content of the products from exporting countries, importing countries, the U.S. in this case, could adopt either of the two approaches to overcoming information challenges in practical implementation. One is to prescribe the tax rates for the imported product based on U.S. domestically predominant method of production for a like product, 
which sets the average embedded carbon content of a particular product (Zhang, 1998; Zhang and Assunção, 2004). This practice is by no means without foundation. For example, the U.S. Secretary of the Treasury has adopted the approach in the tax on imported toxic chemicals under the Superfund Tax (GATT, 1987; Zhang, 1998). An alternative is to set the best available technology (BAT) as the reference technology level and then use the average embedded carbon content of a particular product produced with the BAT in applying border carbon adjustments (Ismer and Neuhoff, 2007). Generally speaking, developing countries will bear a lower cost based on either of the approaches than using the nation-wide average carbon content of imported products for the country of origin, given that less energy-efficient technologies in developing countries produce products of higher embedded carbon contends than those like products produced by more energy-efficient technologies in the U.S. However, to be more defensible, either of the approaches should allow foreign producers to challenge the carbon contents applied to their products to ensure that they will not pay for more than they have actually emitted.

\section{Concluding remarks}

The inclusion of border carbon adjustment measures is widely considered essential to secure passage of any U.S. legislation capping its greenhouse gas emissions. Thus, on the U.S. side, in designing such trade measures, WTO rules need to be carefully scrutinised, and efforts need to be made early on to ensure that the proposed measures comply with them. After all, a conflict between the trade and climate regimes, if it breaks out, helps neither trade nor the global climate. The U.S. needs to explore, with its trading partners, cooperative sectoral approaches to advancing low-carbon technologies and/or concerted mitigation efforts in a given sector at an international level. Moreover, to increase the prospects for a successful WTO defence of the Waxman-Markey type of border adjustment provision, there should be: 1) a period of good faith efforts to reach agreements among the countries concerned before imposing such trade measures; 2) considerations of alternatives to trade provisions that could be reasonably expected to fulfill the same function but are not inconsistent or less inconsistent with the relevant WTO provisions; and 3) trade provisions that can refer to the designated special international reserve allowance 
pool, but should allow importers to submit equivalent emission reduction units that are recognized by international treaties to cover the carbon contents of imported products.

Meanwhile, being targeted by such border carbon adjustment measures, the major developing countries should make the best use of the forums provided under the UNFCCC and its KP to effectively deal with the proposed measures to their advantage (Zhang, 2009b). The Bali Action Plan (BAP) calls for "comparability of efforts" towards climate mitigation actions only among industrialized countries. However, lack of the clearly defined notion of what is comparable has led to diverse interpretations of the concept of comparability. Moreover, there is no equivalent language in the BAP to ensure that developing country actions, whatever might be agreed to at Copenhagen, comparable to those of developed countries. So, some industrialized countries, if not all, have extended the scope of its application beyond industrialized countries themselves, and are considering the term "comparable" as the standard by which to assess the efforts made by all their trading partners in order to decide on whether to impose unilateral trade measures to address their own competitiveness concerns. Such lack of the common understanding will lead each country to define whether other countries have made comparative efforts to its own. This can hardly be objective, and in turn leads one country to misuse unilateral trade measures against other trading partners to address its own competitiveness concerns.

This is not hypothetical. Rather, it is very real as the Lieberman-Warner bill in the U.S. Senate and the Waxman-Markey bill in the U.S. House demonstrated. If such measures became law and were implemented, trading partners might choose to challenge U.S. before WTO. A case like this is likely, given that both the top Chinese official in charge of climate issues and the Brazilian climate ambassador consider the WTO as the proper forum when developing countries are required to purchase emission allowances in the U.S. proposed cap-and-trade regime (Samuelsohn, 2007). This indicates that leading developing countries appear to be comfortable with WTO rules and institutions defending their interests in any dispute that may arise over unilateral trade measures. This is reinforced in the Political Declaration of the Leaders of Brazil, China, India, Mexico and South Africa (the so-called G5) in Sapporo, Japan, July 8, 2008 that "in the negotiations under the Bali Road Map, we urge the international community to focus on 
the core climate change issues rather than inappropriate issues like competitiveness and trade protection measures which are being dealt with in other forums.”

However, the point is that if a case like this really happens before a WTO panel, that panel would likely look to the UNFCCC for guidance on an appropriate standard for the comparability of climate efforts to assess whether that country has followed the international standard when determining comparability. Otherwise, that WTO panel will have no choice but to fall back on the aforementioned Shrimp-Turtle jurisprudence (see Box 2), and would be influenced by the fear of the political fall out from overturning U.S. unilateral trade measures in its domestic climate legislation. If the U.S. measures were allowed to stand, that would undermine the UNFCCC's legitimacy in setting and distributing climate commitments between its parties (Werksman and Houser, 2008). Therefore, as strongly emphasized in my interview in the New York Times (Reuters, 2009), there is a clear need within a climate regime to define comparable efforts towards climate mitigation and adaptation to discipline the use of unilateral trade measures at the international level, taking into account differences in their national circumstances, such as current level of development, per capita GDP, current and historical emissions, emission intensity, and per capita emissions. If well defined, that will provide some reference to WTO panels in examining cases related to comparability issues.

Finally, it should be emphasized that the Waxman-Markey type of border adjustment provision holds out more sticks than carrots to developing countries. If the U.S. and other industrialized countries really want to persuade developing countries to do more to combat climate change, they should first reflect on why developing countries are unwilling to and cannot afford to go beyond the aforementioned third option in the first place. That will require industrialized countries to seriously consider developing countries’ legitimate demand that industrialized countries need to demonstrate that they have taken the lead in reducing their own greenhouse gas emissions, provide significant funding to support developing country’s climate change mitigation and adaptation efforts and to transfer low- or zero-carbon emission technologies at an affordable price to developing countries. Industrialized countries need to provide positive incentives to encourage developing countries to do more. Carrots should serve as the main means. Sticks can be incorporated, but only if they are credible and realistic and serve as a useful supplement to 
push developing countries to take actions or adopt policies and measures earlier than would otherwise have been the case. At a time when the world community is negotiating a post-2012 climate regime, unrealistic border carbon adjustment measures as exemplified in the WaxmanMarkey bill are counterproductive to help to reach such an agreement on comparable climate actions in the negotiations.

\section{References}

Berger, J.R. (1999), Unilateral Trade Measures to Conserve the World’s Living Resources: An Environmental Breakthrough for the GATT in the WTO Sea Turtle Case, Columbia Journal of Environmental Law, Vol. 24, pp. 355-411.

Bhagwati, J. and P.C. Mavroidis (2007), Is Action against US Exports for Failure to Sign Kyoto Protocol WTO-Legal?, World Trade Review, Vol. 6, No. 2, pp. 299-310.

Bounds, A. (2006), EU Trade Chief to Reject 'Green’ Tax Plan, Financial Times, December 17, Available at: http://www.ft.com/cms/s/0/9dc90f34-8def-11db-ae0e0000779e2340.html?nclick_check=1.

Bovenberg, A.L. and L.H. Goulder (2002), Addressing Industry-Distributional Concerns in U.S. Climate Change Policy, Unpublished manuscript, Department of Economics, Stanford University.

Broder, J. (2009), Obama Opposes Trade Sanctions in Climate Bill, New York Times, June 28, Available

at: http://www.nytimes.com/2009/06/29/us/politics/29climate.html?_r=2\&scp=1\&sq=obama\%20 opposes $\% 20$ trade $\% 20$ sanctions\&st=cse.

Charnovitz, S. (2003), Trade and Climate: Potential Conflicts and Synergies, in Pew Center on Global Climate Change, Beyond Kyoto - Advancing the International Effort Against Climate Change, pp. 141-170. 
European Commission (2008), Proposal for a Directive of the European Parliament and of the Council Amending Directive 2003/87/EC so as to Improve and Extend the Greenhouse Gas Emission Allowance Trading System of the Community, COM(2008) 16 final, Brussels.

Genasci, M. (2008), Border Tax Adjustments and Emissions Trading: the Implications of International Trade Law for Policy Design, Carbon and Climate Law Review, Vol. 2, No. 1, pp. 33-42.

General Agreement on Tariffs and Trade (GATT, 1987), United States - Taxes on Petroleum and Certain Imported Substances, Report of the Panel, Adopted on June 17, L/6175, BISD 34S/136, Geneva, Available at: http://www.wto.org/english/res_e/booksp_e/analytic_index_e/introduction_01_e.htm.

General Agreement on Tariffs and Trade (GATT, 1990), Thailand - Restrictions on Importation of and Internal Taxes on Cigarettes, Report of the Panel, DS10/R, Adopted on November 7, BISD 37S/200, Geneva, Available at: http://www.wto.org/english/res_e/booksp_e/analytic_index_e/introduction_01_e.htm.

General Agreement on Tariffs and Trade (GATT, 1994), United States: Restrictions on the Imports of Tuna, Report of the Panel (not adopted), DS29/R, June 16, Geneva, Available at: http://www.wto.org/english/res_e/booksp_e/analytic_index_e/introduction_01_e.htm.

Haverkamp, J. (2008), International Aspects of a Climate Change Cap and Trade Program, Testimony before the Committee on Finance, U.S. Senate, February 14, Available at: http://finance.senate.gov/hearings/testimony/2008test/021408jhtest.pdf.

Houser, T. (2008), Carbon Tariffs - Why Trade Sanctions Won’t Work, China Economic Quarterly, Vol. 12, No. 3, pp. 33-38. 
Houser, T., Bradley, R., Childs, B., Werksman, J. and R. Heilmayr (2008), Leveling The Carbon Playing Field: International Competition and U.S. Climate Policy Design, Peterson Institute For International Economics and World Resources Institute, Washington, DC.

Ismer, R., and K. Neuhoff (2007), Border Tax Adjustment: A Feasible Way to Support Stringent Emission Trading, European Journal of Law and Economics, Vol. 24, No. 2, pp. 137-164.

McBroom, M. (2008), How the IBEW-UWM-Boilermakers-AEP International Proposal Operates within Climate Legislation, June 17, Available

at: http://www.wita.org/index.php?tg=fileman\&idx=viewfile\&idf=189\&id=4\&gr=Y\&path=\&file =WITA-+Climate+Change+-+Overview+of+IBEW-AEP+Proposal+(June+17\%2C+2008).pdf.

Ministry of Commerce of China (MOC of China, 2009), A Statement on "Carbon Tariffs", July 3, Beijing, Available at: http://www.mofcom.gov.cn/aarticle/ae/ag/200907/20090706375686.html, (in Chinese).

Morris, M.G. and E.D. Hill (2007), Trade is the Key to Climate Change, The Energy Daily, Vol. 35, No. 33, February 20.

Parry, Ian W.H., Williams III, R.C. and L.H. Goulder (1999), When Can Carbon Abatement Policies Increase Welfare? The Fundamental Role of Distorted Factor Markets, Journal of Environmental Economics and Management, Vol. 37, No. 1, pp. 52-84.

Reinaud, J. (2008), Issues behind Competitiveness and Carbon Leakage: Focus on Heavy Industry, IEA Information Paper, IEA/OECD, October, Paris.

Reuters (2009), China Says “Carbon Tariffs” Proposals Breach WTO Rules, New York Times, July 3, Available at: http://www.nytimes.com/reuters/2009/07/03/world/international-uk-chinaclimate.html?ref=global-home. 
Samuelsohn, D. (2007), Trade Plan Opposed by China, Brazil and Mexico, Greenwire, September 26, Available at: http://www.earthportal.org/news/?p=507.

Swedish National Board of Trade (2004), Climate and Trade Rule - Harmony or Conflict?, Stockholm.

The Economist (2008), Pollution Law: Trading Dirt, June 7, pp. 42-44.

Werksman, J. and T. Houser (2008), Competitiveness, Leakage and Comparability: Disciplining the Use of Trade Measures under a Post-2012 Climate Agreement, Discussion Paper, World Resources Institute, December, Washington, DC.

World Trade Organization (WTO, 1998), United States - Import Prohibition of Certain Shrimp and Shrimp Products, Report of the Appellate Body, WT/DS58/AB/R, Geneva.

World Trade Organization (WTO, 2001), United States - Import Prohibition of Certain Shrimp and Shrimp Products, Recourse to Article 21.5 of the DSU by Malaysia, Panel Report, WT/DS58/RW, Adopted on November 21,Geneva.

Zhang, Z.X. (1997), The Economics of Energy Policy in China: Implications for Global Climate Change, New Horizons in Environmental Economics Series, Edward Elgar.

Zhang, Z.X. (1998), Greenhouse Gas Emissions Trading and the World Trading System, Journal of World Trade, Vol. 32, No. 5, pp. 219-239.

Zhang, Z.X. (1999), Should the Rules of Allocating Emissions Permits be Harmonised?, Ecological Economics, Vol. 31, No. 1, pp. 11-18.

Zhang, Z.X. (2004), Open Trade with the U.S. without Compromising Canada’s Ability to Comply with its Kyoto Target, Journal of World Trade, Vol. 38, No. 1, pp. 155-182. 
Zhang, Z.X. (2007a), Doing Trade and Climate Policy Together, in Najam, A., Halle, M. and R. Meléndez-Ortiz (Editors), Trade and Environment: A Resource Book, International Institute for Sustainable Development, Canada, and International Center for Trade and Sustainable Development, Geneva.

Zhang, Z.X. (2007b), Why Has China not Embraced a Global Cap-and-Trade Regime?, Climate Policy, Vol. 7, No. 2, pp. 166-170.

Zhang, Z.X. (2009a), Multilateral Trade Measures in a Post-2012 Climate Change Regime?: What Can Be Taken from the Montreal Protocol and the WTO?, Energy Policy, Vol. 37, pp. 5105-5112.

Zhang, Z.X. (2009b), 美国拟征收碳关税 中国当如何应对 (How Should China Respond to the U.S. Proposed Carbon Tariffs?), 《国际石油经济》International Petroleum Economics, Vol. 17, No. 8, pp. 13-16.

Zhang, Z.X. and L. Assunção (2004), Domestic Climate Policy and the WTO, The World Economy, Vol. 27, No. 3, pp. 359-386. 